\title{
PENGAWASAN PROGRAM KUR \\ PADA KANCA BRI UNIT AHMAD YANI \\ KOTA MAKASSAR
}

\author{
Ariani, Muhammad Indris, Alimuddin Said \\ Jurusan Ilmu Administrasi Negara Fisipol Unismuh \\ Jurusan Ilmu Administrasi Negara Fisipol Unismuh \\ Jurusan Ilmu Administrasi Negara Fisipol Unismuh
}

\begin{abstract}
The object of research was to find out the of supervision of credit program in Makassar city at branch office of Bri unit Ahmad Yani. This research is a describe the shape of wualitative service the form internal supervision. This type of research is a case study. The collection of the data used interview, observation and documentation. While techiques to analuze the data used data reduction, data presentation and conclusion. Validity of the data used triangulation of time, resources and techniques. The results showed that the of suerviing credit business Kur program in Makassar city Bri unit of Ahmad Yani unit based on internal control indicator that has been determined by audit bri that is 1) internal audit,2)review, the next is the internal supervision at bri is not good, seen in the of supervision daeler kur
\end{abstract}

Keywords : Implementation of supervision, Service Kur

\begin{abstract}
ABSTRAK
Tujuan penelitian adalah untuk mengetahui pengawasan program Kur pada Kanca Bri Unit Ahmad Yani. Yang jenis penelitian adalah kualitatif dengan menggambarkan bentuk pengawasan internal. Tipe penelitian adalah studi kasus. Dalam pengumpulan data digunakan teknik observasi, wawancara dan dokumentasi. Teknik analisis data digunakan triangulasi yaitu triangulasi sumber, triangulasi metode, triangulasi waktu. Hasil penelitian menunjukkan bahwa pengawasan program Kur di Kota Makassar pada kanca Bri Unit Ahmad Yani dengan berdasarkan indikator pengawasan internal yang telah di tentukan audit Bri yaitu 1)audit internal, 2) review, selanjutnya, pengawasan internal di Bri masih kurang baik, dilihat dalam pengawasan pelaksana penyalur Kur.
\end{abstract}

Kata Kunci : Penerapan pengawasan, pelayanan Kur. 


\section{PENDAHULUAN}

Di Indonesia pelaksanaan program KUR ini telah diperkuat karena telah di keluarkan kebijakan tentang penyaluran Kur diatur oleh pemerintah melalui peraturan Menteri Keuangan No. 135/PMK.05/2008 tentang fasilitas pemerintah hyang telah diubah dengan peraturan Menteri Keuangan No. 10/PMK.05/2009. Dan sesuai dengan Inpres No. 6 tahun 2007 tanggal 8 Juni 2007 tentang kebijakan percepatan.

Pengembangan Sektor Ril dan

Pemberdayaan UMKM serta Nota kesepahaman bersama antara Pemerintah,perbankan dan Perusahaan Penjamin [ada tanggal 9 Oktober 2007 , pemerintah telah meluncurkan program Kur (Kredit Usaha Rakyat) melalui perbankan di seluruh Indonesia.

Bank dan lembaga keuangan bukan bank mempunyai peran penting dalam sistem keuangan, yaitu pengalihan aset, transaksi, likuiditas, dan efisiensi (sigit Triandari dan Totok Budisantoso,2006). Salah satu dari peran tersebut ialah pengalihan aset.
Bank akan memberikan pinjaman kepada pihak yang membutuhkan dan dalam jangka waktu tertentu yang telah disepakati, dalam hal ini yang dimaksudkan adalah fasilitas kredit banyaknya pengangguran, sehingga pemerintah membuat program KUR ini untuk mengatasi kemiskinan yang ada di Indonesia, dengan adanya program Kur ini diharapkan dapat sedikit membantu beban ekonomi, akan tetapi bukan tidak mungkin akan meleset dari tujuan semuila jika tidak dijalankan dengan baik bekerjasama dari semua pihak, baik itu bagian pengawasan bank penyalur kur dan Umkm itu sendiri.

Program kur ini dengan tujuan untuk mengurungi angka kemiskinan dan mengurangi pengangguran ini tentunya, diharapkan dapat berjalan dengan baik dan lancar. Salah satu indikator keberhasilan program tersebut secara produktif dengan meningkatkan dalam untuk pengembangan usaha dan keuntungan dari UMKM tersebut. Sesuai dengan inpres No. 6 tahun2007 tanggal 8 juni 2007 tentang kebijakan percepatan 
pengembangan sektor riil dan pemberdayan UMKM serta nota kesapahaman bersama antar pemerintah, perbankan dan perusahaan menjamin pada tanggal 9 oktober 2007, pemerintah telah meluncurkan program Kur melalui perbankan seluruh Indonesia

Perlunya pengawasan dalam program Kur di Kota Makassar tersebut di Kantor Cabang Bri Unit Ahmad Yani. Peran dalam pengawasan sangat diperlukan agar program Kur tersebut dapat berjalan dengan efektif dan efisien dalam menyalurkan program kur tersebut. Salah satu perumusan pengawasan yang dilakukan pihak dalam penyaluran Kur yaitu anggota komite audit.

Adapun beberapa tahapan yang dilakukan pihak Bank dalam halnya pengawasan antara lain audit internal (Pengawasan internal lingkunga), review (penilaian resiko) dan pengujian pengendalian Manajemen (kegiatan pengendalian dan audit terinci (pemantauan dan pengawasan internal), pelaporan dan tindak lanjut. Dengan adanya audit manajemen diharapkan dapat memperkecil peluang terjadinya resiko pengembalian kredit (kredit macet). Dengan adanya audit officer Manajemen Bank sangat diperlukan agar pemberian kredit dapat efektif dan efisien

Menurut Siagian, 2001:10 Siagian (2001) mendefinisikan audit manajemen sebagai suatu bentukpemeriksaan yang bertujuan untuk meneliti dan menilai kinerja perusahaan yangdisoroti dari sudut pandang peningkatan efisiensi, efektivitas dan produktivitas kerjadalam berbagai komponennya. Audit manajemen merupakan salah satu alat yang digunakan manajemen untuk mengukur dan mengevaluasi kegiatan yang telah dilaksanakan dalam mencapai tujuan perusahaan secara efektif, efisien, dan ekonomis

Ruang lingkup audit manajemen meliputi seluruh aspek kegiatan manajemen. Ruang lingkup ini dapat berupa seluruh kegiatan atau dapat juga hanya mencakup bagian tertentu dari program atau aktivitas yang dilakukan (IBK Bayangkara, 2011: 15

Ruang lingkup audit manajemen meliputi:Auditatas 
pertanggungjawaban keuangan dan ketaatan pada peraturan perundangundangan yang berlaku mencakup penilaian apakah unit kerja.

Melaksanakan program yang ditetapkan sesuai dengan ketentuan organisasi yang berlaku, dan Mengelola penerimaan dan pengeluaran dana sesuai dengan ketentuan yang berlaku.

Audit atas kehematan dan daya guna mencakup penilaian unit kerja: Mengikuti praktik-praktik pengadaan barang/jasa yang sehat.

Mendapatkan jenis, kualitas, dan jumlah sumber daya yang diperlukan dengan biaya terendah yang wajar. Melindungi dan memelihara sumber daya secara layak. Menghindari adanya duplikasi kerja oleh beberapa petugas.

Audit manajemen juga meliputi audit hasil guna (efektivitas) yang mencakup penilaian: Tujuan dan sasaran sudah sesuai, cocok, relevan dengan keinginan pembuat undang-undang atau ketentuan yang berlaku. Sejauh mana hasil suatu program dan kegiatan mencapai suatu tingkat yang diinginkan.

Pelaksanaan program telah diarahkan kepada penerima sesuai dengan apa yang telah ditetapkan pada saat perumusan program.

Audit pendahuluan dilakukan untuk mendapatkan informasi latar belakang terhadap objek audit yang dilakukan. Di samping itu, pada audit ini juga dilakukan penelaahan terhadap berbagai peraturan, ketentuan dan kebijakan berkaitan dengan aktivitas yang diaudit, serta menganalisis berbagai informasi yang telah diperoleh untuk mengindentifikasi hal-hal yang potensial mengandung kelemahan pada perusahaan yang diaudit. Auditor mungkin menggunakan daftar pertanyaan, flow chart, tanya jawab, laporan manajemen, dan observasi dalam pelaksanaan audit pendahuluan. Daftar pertanyaan terdiri dari pertanyaan-pertanyaan yang berhubungan dengan masalah yang memengaruhi efektivitas dan performa operasi. Auditor kemudian akan menilai jawaban yang diperoleh, kemudian auditor mengumpulkan bukti-bukti untuk memperkuat jawaban yang diterima.

Review dan Pengujian Pengendalian Manajemen Pada tahap 
ini auditor melakukan review dan pengujian terhadap pengendalian manajemen objek audit, dengan tujuan untuk menilai efektivitas pengendalian manajemen dalam mendukung pencapaian tujuan perusahaan. Dari hasil pengujian ini, auditor dapat lebih memahami pengendalian yang berlaku pada objek audit sehingga dengan lebih mudah dapat diketahui potensipotensi terjadinya kelemahan pada berbagai aktivitas yang dilakukan. Jika dihubungkan dengan tujuan audit sementara yang telah dibuat pada audit pendahuluan, hasil pengujian pengendalian manajemen ini dapat mendukung tujuan audit sementara tersebut menjadi tujuan audit sesungguhnya, atau mungkin ada beberapa tujuan audit sementara yang gugur, karena tidak cukup (sulit memperoleh) bukti-bukti yang mendukung tujuan audit tersebut.

Audit Terinci Pada tahap ini auditor melakukan pengumpulan bukti yang cukup dan kompeten untuk mendukung tujuan audit yang telah dilakukan. Temuan yang cukup, relevan, dan kompeten dalam tahap ini disajikan dalam suatu Kertas
Kerja Audit (KKA) untuk mendukung kesimpulan audit yang dibuat dan rekomendasi yang diberikan. Kertas kerja dapat diorganisir berdasarkan subunit dari usaha yang diaudit (seperti berdasarkan cabang, bagian), urutan prosedur audit dilaksanakan (seperti audit pendahuluan, bukti) atau setiap sistem logis yang mempertinggi pemahaman auditor terhadap pekerjaan yang dilakukan. Tujuan mengumpulkan bukti-bukti adalah untuk mendapatkan dasar faktual dalam menilai kriteria performa yang sebelumnya diidentifikasi

Pelaporan Tahapan ini bertujuan untuk mengomunikasikan hasil audit termasuk rekomendasi yang diberikan kepada berbagai pihak yang berkepentingan. Hal ini penting untuk meyakinkan pihak manajemen tentang keabsahan hasil audit dan mendorong pihak-pihak yang berwenang untuk melakukan perbaikan terhadap berbagai kelemahan yang ditemukan.

Tindak Lanjut Sebagai tahap akhir dari audit manajemen, tindak lanjut bertujuan untuk mendorong pihak-pihak yang berwenang untuk 
melaksanakan tindak lanjut sesuai dengan rekomendasi yang diberikan. Auditor tidak memiliki wewenang untuk mengharuskan tindak lanjut sesuai dengan rekomendasi yang diberikan. Oleh karena itu, rekomendasi yang disajikan dalam laporan audit seharusnya sudah merupakan hasil diskusi dengan berbagai pihak yang berkepentingan dengan tindakan perbaikan tersebut. Suatu rekomendasi yang tidak disepakati oleh objek audit akan sangat berpengaruh pada pelaksanaan tindak lanjutnya. Hasil audit menjadi kurang bermakna apabila rekomendasi yang diberikan tidak ditindaklanjuti oleh pihak yang diaudit.

\section{METODE PENELITIAN}

Penelitian ini telah dilakukan selama 2 bulan dari bulan Mei sampai Juli 2017. Penelitian ini dilaksanakan di kantor Cabang Bank Rakyat Indonesia unit Ahmad Yani Kota Makassar Adapun alasan penulis memilih lokasi tersebut karena merupakan tempat dimana dilaksanakannya kegiatan program Kur yang terbesar di salah satu kantor cabang besar yang berada di Kota Makassar

Penelitian menggunakan tipe fenomenology. Sumber data adalah data primer dan sekunder. Informan penelitian yaitu staf pelayanan Kur dan nasabah Kur di Bank Bri Ahmad Yani. Dalam penelitian ini, pengumpulan data dilakukan melalui beberapa tekhnik yaitu wawancara, observasi, dan dokumentasi. Teknik pengabsahan data yaitu dengan teknik triangulasi. Teknik analisa data yaitu pengumpulan informasi melalui wawancara, reduksi data, penyajian data, dan penarikan kesimpulan atau verifikasi.

\section{HASIL DAN PEMBAHASAN}

Ketepatan sasaran program yaitu sejauhmana peserta program tepat dengan sasaranyang sudah ditentukan sebelumnya. Sasaran program JARING yang dimaksud adalah peningkatan pembiayaan di sektor kelautan dan perikanan yang terus bertumbuh serta mendorong perluasan akses masyarakat di Desa Boddia Kecamatan Galesong terhadap sektor jasa keuangan. Dari hasil wawancara yang dilakukan peneliti dapat mengetahui Sasaran 
program JARING di Desa Boddia Kecamatan Galesong Kabupaten Takalar belum Sesuai dengan sasaran yang ditentukan sebelumnya.

OJK (Otoritas

Jasa

Keuangan) bersama KKP

(Kementrian Kelautan Dan

Perikanan)meluncurkan program

JARING dengan sasaran utama ialah peningkatan pertumbuhan

pembiayaan di sektor kelautan dan perikanan (KP).

Audit pendahuluan dilakukan untuk mendapatkan informasi latar belakang terhadap objek audit yang dilakukan.Pada tahap audit pendahuluan ini didapatkan informasi mengenai BRI secara umum (kondisi/condition) dan informasi mengenai BRI secara khusus (kriteria/criteria), yang meliputi: Deskripsi Data Umum Perusahaan, yang terdiri dari: Sejarah singkat Bank Rakyat Indonesia. Visi dan misi Bank Rakyat Indonesia. Struktur Bank Rakyat Indonesia. Deskripsi Data Khusus Perusahaan, yang terdiri dari: Struktur organisasi BRI UnitKuwarasan, Gombong, Kebumen. Tugas dan wewenang masing-masing jabatan. Prosedur pemberian Kredit Usaha Rakyat pada BRI Unit Ahmad Yani Kota Makassar

Tahap review dan pengujian pengendalian manajemen atas pemberian Kredit Usaha Rakyat (KUR) pada BRI Unit Ahmad Yani Kota Makassar dimaksudkan untuk menilai efektivitas pengendalian manajemen Kredit Usaha Rakyat dalam mendukung pencapaian tujuan BRI Unit Ahmad Yani Kota Makassar dengan mengetahui bagaimana pengendalian internal pada setiap tahapan pemberian Kredit Usaha Rakyat. Hasil review dan pengujian pengendalian manajemen dianalisis berdasarkan program audit (yang tertera dalam lampiran) meliputi: Dilakukan pengecekan ulang setelah registrasi calon debitur oleh Customer Service. Mantri melakukan BI checking terhadap identitas calon debitur. Mantri mencocokkan fotokopi bukti diri/identitas lain sesuai dengan aslinya saat survei.

Audit terinci atas pemberian Kredit Usaha Rakyat (KUR) pada BRI Unit Ahmad Yani Kota Makassardimaksudkan untuk 
mengumpulkan bukti yang cukup kompeten untuk mendukung tujuan audit. Hasil dari audit terinci yang dilakukan oleh penulis di BRI Unit Ahmad Yani Kota Makassaradalah sebagai berikut Tahap Permohonan Kredit, analisis kredit, pemberian kredit , pemutusan kredit dan pengawasan kredit.

Tahap Permohonan Kredit dilihat dalam suatu Kondisi Calon debitur yang akan mengajukan permohonan Kredit Usaha Rakyat, mengajukan surat permohonan ke Customer Service BRI Unit Kuwarasan dengan membawa kelengkapan identitas. Customer Service memeriksa kelengkapan identitas yang berupa fotokopi KTP, fotokopi KK, dan Surat Keterangan Usaha, sedangkan calon debitur mengisi formulir permohonan Kredit Usaha Rakyat dan ditandatangani.

Beberapa administrasi terjadi kesalahan seperti adanya KTP yang sudah mati ataupun ketidakbenaran usaha yang dimiliki oleh calon debitur.

Penyebab Beberapa kelalaian Customer Service ditemukan pada saat registrasi/permohonan kredit, khususnya pada kelengkapan dan keaslian berkas-berkas fotokopi identitas diri yang berupa fotokopi KTP, fotokopi Kartu Keluarga (KK), dan Surat Keterangan Usaha yang diberikan oleh calon debitur kepada Customer Service.

Akibat Kesalahan yang
paling banyak dijumpai adalah
adanya KTP dari calon debitur yang sudah mati namun Customer Service tetap meloloskan administrasi tersebut. Selain itu, usaha calon debitur ternyata tidak sesuai dengan kenyataan di lapangan. Akibat dari kelalaian itu adalah Mantri/Account Officer saat melakukan survei lapangan, Mantri harus mengulang pemeriksaan dari awal karena data dari Customer Service tidak sesuai dengan persyaratan. Waktu yang digunakan menjadi kurang efektif. Tahap Analisis Kredit/Pemeriksaan dilihat dalam Kondisi Setelah syarat-syarat dan berkas-berkas dilengkapi, Mantri (Account Officer) melakukan BI checking atas nama calon debitur tersebut. Jika calon debitur memiliki riwayat yang baik dalam hal pinjaman, maka Mantri 
akanmelakukan survei. Namun, jika calon debitur memiliki riwayat yang kurang baik (blacklist) maka secara langsung permohonan pinjaman calon debitur tersebut ditolak.

Kriteria Mantri mencocokkan fotokopi bukti diri/identitas lain (fotokopi KTP, fotokopi Kartu Keluarga, Surat Keterangan Usaha) sesuai dengan aslinya. Mantri menanyakan hal-hal yang berhubungan dengan usaha calon debitur. Tujuannya adalah untuk menganalisis apakah calon debitur mampu mengembalikan pinjaman atau tidak.

\section{Penyebab Kelalaian}

Customer Service yang meloloskan calon debitur dengan administrasi yang tidak sesuai dengan persyaratan. Kelalaian

Mantri/Account Officer dalam melakukan analisis pendapatan calon debitur yang seharusnya lebih dari $75 \%$ dari pendapatan usaha calon debitur.

Tahap Pemberian Putusan Kredit Kondisi Setelah analisis yang dilakukan oleh Mantri dan hasilnya diserahkan kepada Kepala Unit, pihak BRI Unit Kuwarasan akan mengkonfirmasikannya kepada calon debitur. Kepala Unit akan memastikan dokumen-dokumen pendukung keputusan seperti fotokopi KTP, fotokopi KK, Surat Keterangan Usaha, dan formulir permohonan pinjaman Kredit Usaha Rakyat.

Kriteria Analisis yang dilakukan telah memenuhi syarat 5C. Syarat tersebut adalah: Character yaitu sifat dari calon debitur untuk mengetahui sejauh mana calon debitur memiliki kemauan dan itikad untuk memenuhi kewajibannya membayar angsuran pinjaman. Capacity yaitu menganalisis kemampuan calon debitur dalam melangsungkan usahanya guna memperoleh laba yang diharapkan. Hal ini berfungsi untuk mengukur kemampuan calon debitur membayar angsuran dengan tepat waktu.

Capital yaitu jumlah modal sendiri yang dimiliki calon debitur. Hal ini berfungsi sebagai alat indikator kesungguhan dan tanggung jawab debitur dalam melangsungkan usahanya karena ikut menanggung resiko dalam kegagalan usahanya.

Collateral yaitu barang- 
barang yang diserahkan calon debitur sebagai jaminan kredit yang diterimanya. Maka dari itu sebelumnya, pengikatan harus diteliti dari segi yuridisnya yaitu apakah barang-barang yang dijaminkan itu (berupa fotokopi KTP, fotokopi KK, dan Surat Keterangan Usaha) masih berlaku, lengkap, sah, dan berkekuatan hukum.

Condition of economy yaitu keadaan ekonomi yang nantinya akan mempengaruhi kelangsungan usaha calon debitur yang pada akhirnya akan mempengaruhi kemampuannya dalam membayar kewajibannya.

Tahap Pencairan Kredit/Akad

Kredit Kondisi Saat putusan pemberian kredit telah dikeluarkan, Customer Service menyiapkan semua syarat-syarat (berupa fotokopi KTP, fotokopi KK, Surat Keterangan Usaha, dan formulir permohonan Kredit Usaha Rakyat yang telah diisi) yang harus diserahkan oleh Kepala Unit sebelum Kredit Usaha Rakyat tersebut dicairkan. Kondisi yang sering ditemukan adalah adanya kesalahan penulisan nominal pada berkas-berkas pendukung pencairan kredit yang dibuat oleh Customer
Service yang berupa kwitansikwitansi (kwitansi pembayaran, kwitansi pinjaman, dan kwitansi materai) sebagai syarat sebelum kredit dicairkan.

Kriteria Dokumen yang harus dipersiapkan dan diisi lengkap sebagai persyaratan pencairan kredit adalah:Kwitansi pembayaran, Kwitansi pinjaman, Kwitansi materai,Surat Pengakuan Hutang yang telah ditandatangani Kepala Unit, Rekening pinjaman, Formulir permohonan pinjaman Kredit Usaha Rakyat yang telah ditandatangani oleh Mantri dan Kepala Unit yang selanjutnya diserahkan ke Teller untuk pencairan Kredit Usaha Rakyat.

Penyebab Adanya kesalahan nominal uang saat penyerahan berkasberkas pendukung (kwitansi pembayaran, kwitansi pinjaman, kwitansi materai, surat pengakuan hutang, rekening pinjaman, dan formulir permohonan pinjaman Kredit Usaha Rakyat) ke Teller yang akan dicairkan.

Tahap Pengawasan Kredit Kondisi Tujuan dari dilakukannya pengawasan kredit adalah agar 
program pemberian Kredit Usaha Rakyat bisa berjalan sesuai prosedur dan dapat berjalan efektif serta mampu mencapai target tahunan yang telah ditetapkan saat perencanaan tahunan. Pengawasan lebih banyak dilakukan oleh Kepala Unit dan dibantu oleh masing-masing jabatan yang berkaitan dengan program pemberian Kredit Usaha Rakyat.

Di BRI Unit Kuwarasan tidak terdapat kredit macet karena selalu ada penagihan yang dilakukan oleh Mantri. Ada batasan pembayaran, yakni 270 hari, jika sudah melewati batas hari diberikan surat penjaminan yang selanjutnya akan dijaminkan oleh perusahaan penjamin.

Karena adanya pengawasan yang baik serta masing-masing jabatan melaksanakan tugas dan wewenangnya dengan baik, BRI Unit Ahmad Yani dalam hal Kredit Usaha Rakyat telah mencapai target nominal Kredit Usaha Rakyat (Rp 2.486.764.000,00) dan target debitur (364 debitur).

Kriteria Kepala Unit melakukan pertemuan rutin dengan pegawai Kredit Usaha Rakyat BRI
Unit Kuwarasan untuk membahas rencana-rencana kerja yang berkaitan dengan pelaksanaan program Kredit Usaha Rakyat. Adanya peneguran tapi bukan denda ataupun somasi yang akan dilakukan oleh pihak BRI jika terdapat debitur yang lalai dalam pembayaran angsuran pinjaman.

Ada pengawasan terhadap pengelolaan Kredit Usaha Rakyat pada debitur yang memanfaatkan program Kredit Usaha Rakyat. Ada pembinaan dengan pengarahan pinjaman Kredit Usaha Rakyat yang ditujukan untuk modal usaha.

Penyebab Masing-masing pegawai memahami dan melakukan tugas serta wewenangnya dengan baik dalam program pemberian Kredit Usaha Rakyat. Pengawasan dari Kepala Unit telah berjalan dengan baik.

Akibat Tercapainya target nominal dan target debitur tahunan pada periode 2012 mencerminkan adanya pengawasan kredit yang telah dilakukan dengan baik.

Prosedur Pemberian Kredit Usaha Rakyat pada BRI Unit Ahmad Yani Kota MakassarBerdasarkan hasil penelitian penulis di kantor BRI 
Unit Kuwarasan Cabang Gombong yang dilakukan serta hasil wawancara yang dilakukan penulis dengan Mantri (Account Officer/AO), Reza Yuris Diar, SH pada hari Sabtu, 26 Januari 2013, maka penulis dapat mengemukakan bahwa proses pemberian KUR dilakukan secara bertahap yaitu sebagai berikut:

Tahap

Permohonan

KreditCalon debitur mengajukan permohonan Kredit Usaha Rakyat (KUR) secara tertulis kepada pihak BRI Unit Ahmad Yani Kota Makassar. Calon debitur KUR datang ke kantor BRI Unit Ahmad Yani, kemudian dengan dibantu oleh Customer Service, calon debitur KUR mengisi formulir pendaftaran atau formulir permohonan KUR yang sudahdisediakan pihak bank,kemudian ditandatangani oleh pemohon (hasil wawancara dengan Reza Yuris Diar, SH selaku Mantri BRI Unit Ahmad Yani Kota Makassar Sabtu, 26 juni 2017). Calon debitur Kredit Usaha Rakyat diharuskan memenuhi persyaratan yang telah ditetapkan dalam hal pengajuan permohonan Kredit Usaha Rakyat. Kredit Usaha Rakyat diperkenalkan sebagai kredit yang mudah didapat, maka syarat-syarat yang ditetapkan sangat sederhana. Syarat-syarat yang perlu disertakan adalah bukti identitas diri berupa fotokopi Kartu Tanda Penduduk (KTP), fotokopi Kartu Keluarga (KK), dan Surat Keterangan Usaha. Tahap Analisis Kredit/ Tahap Pemeriksaan BRI Unit Ahmad Yani Kota Makassar dalam melakukan analisis kredit mempunyai kebijakan sendiri yang tentunya tetap berpedoman pada arahan Bank Indonesia. Laporan Keuangan calon debitur merupakan salah satu data pokok mutlak dalam hal analisis. Tahap Pemberian Putusan Kredit Tahap ini, calon debitur akan memperoleh keputusan kredit yang berisi persetujuan akan adanya pemberian Kredit Usaha Rakyat sesuai permohonan yang diajukannya.

Keputusan persetujuan permohonan kredit berupa mengabulkan sebagian atau seluruh permohonan kredit dari calon debitur. Pihak BRI Unit Kuwarasan akan memberitahukan kepada calon debitur untuk mengkonfirmasi 
kembali beberapa hari menurut hari yang telah ditentukan oleh pihak bank setelah pengajuan permohonan kredit. Biasanya pemberian putusan dilakukan tiga sampai lima hari setelah pendaftaran permohonan kredit usaha rakyat (hasil wawancara dengan Reza Yuris Diar, SH selaku Mantri/Account Officer BRI Unit Ahmad Yani Kota Makassar Senin, 28 Juni 2017 )

Tahap Pencairan Kredit/Akad Kredit. Setelah semua persyaratan terpenuhi dan pemberian KUR diikat oleh perjanjian kredit maka debitur dapat mengambil dana pinjaman yang telah dimohonkan kepada bagian Teller BRI Unit Ahmad YaniTahap akad kredit/ pencairan meliputi beberapa tahap yaitu tahap persiapan pencairan, penandatangan perjanjian pencairan kredit, fiat bayar dan pembayaran pencairan kredit (hasil wawancara dengan Reza Yuris Diar, SH selaku Mantri/Account Officer pada BRI Unit Ahmad Yani Kota Makassar Senin, 28 Juni 2017.

BRI merupakan perusahaan yang memiliki tingkat kerahasiaan yang tinggi. Peneliti tidak diperbolehkan untuk mendapatkan
SOP (Standar Operasional Perusahaan) yang bagi sebuah penelitian audit merupakan kunci utama penelitian. Hal ini dapat berimplikasi pada objektivitas data yang diperoleh oleh peneliti. Namun, prosedur perusahaan dapat peneliti peroleh dari wawancara maupun kuesioner yang diajukan kepada pihak-pihak yang berkaitan dengan program pemberian Kredit Usaha Rakyat pada BRI Unit Ahmad Yani Kota Makassar

Pengawasan kredit perlu dilakukan agar Kredit Usaha Rakyat berjalan sesuai dengan prosedurnya dan dapat mencapai tujuan atau target yang telah ditetapkan oleh BRI. Pengawasan Kredit Usaha Rakyat pada BRI Unit Kuwarasan, Gombong, Kebumen telah berjalan efektif. Hal tersebut dapat terlihat dari tercapainya target nominal dan target debitur tahunan yang telah ditetapkan oleh BRI. Selain itu kinerja yang baik dari masingmasing pegawai menunjukkan adanya pemahaman yang baik pula tentang tugas dan wewenang masing-masing pegawai dan dibantu dengan adanya pengawasan yang baik dari Kepala 
Unit maupun dari pejabat-pejabat BRI.

\section{KESIMPULAN}

Berdasarkan hasil penelitian yang dilakukan penulis menyimpulkan sebagai berikut :Audit pendahuluan yang telah dilakukan oleh peneliti merupakan tahap awal peneliti menganalisis pemberian Kredit Usaha Rakyat pada RI Unit Ahmad Yani Kota Makassar. Pada tahap audit pendahuluan ini didapatkan informasi mengenai BRI secara umum (kondisi/condition) dan informasi mengenai BRI secara khusus

Tahap review dan pengujian pengendalian manajemen dimaksudkan untuk menilai efektivitas pengendalian manajemen dengan mengetahui pengendalian internal pada setiap tahapan pemberian Kredit Usaha Rakyat. Tahap review dan pengujian pengendalian manajemen yang telah dilakukan oleh peneliti menghasilkan kesimpulan bahwa sistem pengendalian manajemen yang dilakukan pada pemberian
Kredit Usaha Rakyat telah berjalan efektif. Tidak terdapat temuan kelemahan yang mengakibatkan pengendalian manajemen tidak berjalan efektif.

Tahap audit terinci telah dilakukan oleh peneliti. Pada tahapan ini peneliti mengumpulkan bukti yang cukup kompeten dan menganalisisnya menjadi empat elemen, yaitu kondisi, kriteria, sebab, dan akibat. Dari analisis data yang telah dilakukan, audit terinci pada pemberian Kredit Usaha Rakyat telah berjalan efektif walaupun terdapat kelemahan berupa kelalaian. Namun, kelemahan tersebut tidak memiliki dampak yang signifikan terhadap pemberian Kredit Usaha Rakyat pada RI Unit Ahmad Yani Kota Makassar.

Kelalaian yang terjadi bisa mengakibatkan pemberian Kredit Usaha Rakyat (KUR) berjalan tidak efektif. Oleh karena itu, pelatihan diperlukan saat masing-masing pegawai telah memahami tugas dan wewenangnya masing-masing untuk mematangkan dan melatih masingmasing pegawai agar dapat bekerja sesuai dengan tugas dan 
wewenangnya masing-masing.

Pelatihan setelah pegawai mulai bekerja juga dilakukan agar tidak terdapat duplikasi pekerjaan sehingga dapat mengurangi ketidakefektifan pekerjaan.

\section{DAFTAR PUSTAKA}

Budiani, Ni Wayan.2007. Efektivitas Program Penanggulangan Pengangguran Karang Taruna "Eka Taruna Bhakti" Desa SumertaKelod Kecamatan Denpasar Timur Kota Denpasar.Jurnal Ekonomi dan Sosial INPUT.

Hamid, Farida, 2007. Kamus Ilmiah Populer. Titik Terang, Jakarta.

Indrawijaya, Adam Ibrahim.2010.Teori,Perilaku, Dan Budaya Organisasi.RefikaAditama.B andung.

Kurniawan,Agung.2005.Transformai Pelayanan Publik. Yogyakarta : Pembaharuan.

Mahmudi,2005.Manajemen Kinerja Sektor Publik. Yogyakarta : UPP AMP YKPN.

Peraturan pemerintah No. 50 Tahun 2015 Tentang Pemberdayaan Nelayan Kecil Dan Pembudidaya Ikan Kecil.

Sedarmayanti.2009.sumberdaya manusia dan efektivitas kerja. CV. Mandar Maju.Bandung
Siagian,Sondang.P.2001.”Manajeme

n Sumberdaya

Manusia".Bumi Aksara, Jakarta

Subagyo,

Ahmad

Wito.2000.Efektivitas

Program Penanggulangan

Kemiskinan Dalam

Pemberdayaan Masyarakat

Pedesaan.Yogyakarta.UGM

Undang-undang Republik Indonesia No.17 Tahun 2007 tentang Rencana Pengembangan Jangka Panjang Nasional Dari Tahun 2005-2025

Wahyuningsih,D.2005.Efektivitas

Pemberdayaan Masyarakat Dalam Pemabngunan Sarana Dan Prasarana Lingkungan Dikelurahan Salaman Mloyo Kabupaten Semarang. Fakultas Teknik Universitas Diponegoro. 
